\title{
Questões metanarrativas no documentário de arquivo: 0 ato de extrair a natureza do material pelas imagens ${ }^{1}$
}

\author{
Rafael de Souza Barbosa \\ Universidade Federal de Minas Gerais (UFMG), Brasil
}

\begin{abstract}
Just over a decade separate the films Santiago (2006) and In the intense now (2017), by João Moreira Salles. Despite the temporal detachment, both share the director's essay gesture on the archive footage. The proposal of this article is to set a comparison between the two films, establishing their interlocutions, their approximations, but also their distancing. We seek to show how each film promotes the fold of the past with the present in the mainstay of what we call archeology of image, the act of digging the files and reworking them in the discourse.

For JMS, the documentary film contains two distinct natures: it is, at the same time, the record of something that happened in the world but also a narrative, i.e., a rhetoric built on what was recorded. This rhetoric comes from examining the nature of images, that triggers the discourse in the form of voice-over, or from its confrontation with other documents (imagery/ sonorous). This article is intended to analyze how this metanarrative is constituted in his essay films. A process that goes through the material and seeks to understand what the files evoke from the intimate memory, but also what they evoke as an image.
\end{abstract}

Keywords: Documentary, Archive, Essay Film, Metanarrative, João Moreira Salles

\section{Introdução}

Este artigo se propõe a investigar o documentário de João Moreira Salles enquanto dispositivo ensaístico que coloca o fazer fílmico sob suspeita a partir da análise comparada de Santiago (2006) e No intenso agora (2017). Ao promover esse cotejo, buscaremos examinar como a arqueologia das imagens incita a dobra do passado com o presente e conduz os documentários a uma metanarrativa, ou seja, uma inflexão sobre a sua própria estrutura e seus mecanismos intrínsecos.

Para João Moreira Salles, a função do documentário reside na tensão da fronteira. O grande documentário é aquele que amplia a gramática do cinema e a torna mais rica e complexa. Sendo assim, estudar os seus filmes-ensaio passa a ser também um exercício de análise tanto das formas de representação do outro quanto da escrita de si, da expedição a camadas temporais sedimentadas nas imagens de arquivo, da reapropriação do passado, da arquitetura da memória e da maneira como tudo isso é organizado (montado) em narrativas ora refratárias (filmes que interrogam filmes), ora autorreflexivas (filmes que se desenham na experiência de si).

Santiago é um documentário sobre o malogro de um filme não montado. Nele, João Moreira Salles propõe uma reflexão sobre o material bruto do documentário que tentou produzir em 1992, mas que na época não foi finalizado. Durante cinco dias, o cineasta filmou uma série de entrevistas com Santiago, antigo mordomo da família, um personagem de vasto repertório erudito e cultura idiossincrática. Ao revisitar 13 anos depois as imagens abandonadas na montagem, o diretor revira os arquivos já sedimentados e imprime no filme uma nova camada temporal - que separa a filmagem de 1992 da edição de 2005/2006 - onde tece o testemunho sobre a memória, o devir e sobre a própria natureza do fazer documentário.

No intenso agora remota à produção de Santiago. Foi nessa época que o diretor percorreu os arquivos de sua família e descobriu dois rolos de filmes 16 $\mathrm{mm}$ feitos de modo caseiro por sua mãe em uma viagem com um grupo de amigos na China, em 1966, durante a fase inicial e manifestadamente mais forte da Revolução Cultural. Às cenas da China somam-se imagens do maio de 1968 na França, da Primavera de Praga em meio a dominação da União Soviética e, em menor medida, do Brasil. NIA mistura imagens de documentários, televisão, fotografias, áudio e filmes amadores. São dezenas de arquivos postos em análise pelo diretor. $\mathrm{Na}$ esteira do filmeensaio, o documentário interroga como as pessoas que participaram daqueles acontecimentos - vividos com alegria e euforia - seguiram adiante depois do arrefecimento das paixões e do desencanto. O registro amador de Elisa Gonçalves, em um contexto em tudo oposto ao seu, permaneceu oculto por quase 40 anos. A descoberta desse material dá origem ao filme, um relato pessoal sobre a natureza efêmera dos momentos de grande intensidade emocional.

Ao desaterrar os arquivos em seus filmes, e uma vez restabelecido o passado, é importante interrogar de que maneira João Moreira Salles faz uso das construções metanarrativas e com qual finalidade? Qual o trânsito estabelecido entre a imagem e o contingente, entre os rastros e o seu processo de retomada, entre a montagem e o discurso face ao esquecimento e aos silêncios imanentes às imagens de arquivo?

Entender esse encontro de temporalidades é um convite à reflexão sobre as imagens em sua forma pragmática, mas também arqueológica. São essas indagações que nos orientam neste trabalho. Investigar a opacidade das imagens que se configuram na tensão entre o arquivo, enquanto objeto, e o ensaio, como estratégia reflexiva ou mesmo confessional, é, assim, uma maneira de colocar sob suspeita e problematizar o próprio fazer documental contemporâneo.

$\mathrm{Na}$ primeira parte do artigo, buscamos traçar o caráter extensivo da metanarrativa, analisando alguns pontos de interseção a partir das ideias de metalinguagem, metafilme/metacinema, mise en abyme e reflexividade no cinema. Na segunda parte, 
procuramos associar essa proposta com o gesto ensaístico do diretor, tentando nos aproximar daquilo que ele chama de análise da natureza das imagens. Por fim, na terceira parte, trazemos as discussões para os filmes, com base na observação da voz over, da montagem e do antecampo.

Como ferramenta metodológica, adotamos a análise fílmica, percebendo-a como a atividade que perscruta o filme ao detalhe em um duplo exercício de decompor, ou seja, descrever, e interpretar, estabelecendo e compreendendo as relações entre os elementos decompostos (Vanoye e Goliot-Leté 1994, 15). Aumont e Marie (2004, 45-46) elencam os três principais instrumentos e técnicas para a análise que foram empregados nesta pesquisa: os instrumentos descritivos (que auxiliam na apreensão e memorização do filme), os instrumentos citacionais (que realizam um estado intermediário entre o filme e sua análise) e os instrumentos documentais (que incorporam informações provenientes de fontes exteriores ao filme).

\section{Pontos de interseção da metanarativa}

Embora haja alguns esforços para uma taxinomia da metanarrativa no cinema (cf. Chinita 2013a), o termo ainda caminha longe de uma definição inequívoca e perene. De antemão, o vocábulo já traz consigo uma informação que nos é cara: o prefixo meta-, que aponta tanto para um desejo de transcendência quanto para uma inflexão sobre si mesma. É tanto uma narrativa que atravessa os seus próprios métodos, como uma narrativa que busca refletir sobre si. Concomitantemente, o termo evoca uma série de outros correlatos (metalinguagem, metafilme/metacinema, mise en abyme, reflexividade), muitos advindos, principalmente, do campo da literatura, onde o cinema sempre bebeu da fonte. É axiomático que essa transposição não ocorre sem imbricamentos. Alguns teóricos preferem nem fazer a distinção entre certos termos. Metz, por exemplo, vai colocar a reflexividade se não como sinônimo de mise en abyme, ao menos como uma parte coextensiva (Limoges 2015, 01).

No intuito de avançarmos em uma direção comum, sem o risco de nos perdermos nessa profusão conceitual, procuraremos aqui pontuar algumas questões da metalinguagem, do metafilme/ metacinema, da reflexividade e da mise en abyme na tentativa de compreender a dimensão extensiva da metanarrativa, principalmente quando formos buscá-la nas imagens dos documentários que formam o objeto desta pesquisa.

Ao deter-se sobre a metalinguagem no cinema, Andrade $(1999,16)$ destaca sua capacidade autorreferencial, uma espécie de "metalinguagem na estrutura", que torna patente o código e remete ao seu arranjo, no qual "o discurso se apresenta de forma explícita, referindo-se ao próprio cinema, seja através de citações ou mesmo na relação do público com o reconhecimento deste discurso". De certo modo, a metalinguagem convoca o inventário imagético do espectador. Nesse sentido, os filmes que utilizam o recurso "procuram passar a limpo o cinema existente anteriormente, relendo-o e, assim, reaproveitando as possibilidades de variações dentro do já referendado" (ibid., 175).

A explicitação do discurso é também o cerne do metafilme/metacinema, a "filmagem do filme" ou "cinema no cinema", uma referência intertextual que acompanha o cinema desde as suas origens. A exposição dos meios de produção (ou das histórias do mundo do cinema) tem por vezes um caráter anti-ilusionista, que chama a atenção para a feitura do filme, consequentemente, implica uma reflexão sobre suas regras intrínsecas. Especificamente no documentário, todo filme de arquivo não deixa de ser um metafilme, uma vez que se origina de imagens e áudios preexistentes em outros filmes (de família, institucionais, de cinejornais ou mesmo de outro documentário). Nos interessa, então, analisar como esse jogo pode ser tramado de forma mais complexa.

Se a metalinguagem já aponta para si, expondo seus códigos internos, a mise en abyme acentua essa característica pondo-a em camadas recursivas (tomando como referência a imagem, seria, por exemplo, a imagem dentro da imagem, dentro da imagem, de maneira sucessiva, como em um espelho posto defronte a outro). A mise en abyme, ou construção em abismo, de modo geral é associada à "incrustação de uma narrativa na outra", conforme lembra Aumont $(2003,60)$, um termo proposto pelo escritor francês André Gide (1893). Abraçado por diferentes campos das artes, o mecanismo discursivo foi dilatado, empregado para análises que vão desde O casal Arnolfini, pintura de 1434, de Jan van Eick, passando por As Meninas (1965), de Diego Velázquez, até o efeito Droste ${ }^{2}$, sobretudo na fotografia e na ilustração (como a embalagem de Pó Royal). Chinita (2013b) ressalta o caráter potencializador da imagem na mise en abyme. Quanto mais pictórica a arte, mais a "instantaneidade da representação visual permite percepcionar ao mesmo tempo todos os encaixamentos". $\mathrm{Na}$ literatura, isso esbarra com a capacidade de memória do leitor. No cinema, ao invés, "a multiplicidade de enquadramentos potencia um maior questionar da nossa própria realidade de videntes externos ao filme" (Chinita 2013b, 139).

Embora a reflexividade seja tratada por alguns estudiosos de maneira metacinematográfica (expressada pela exposição dos dispositivos cinematográficos no quadro) ou dentro de uma reflexividade fílmica (em citações, homenagens e paródias), como resume a tabela de Limoges (2015, 03), este conceito vem ganhando prolongamentos que tornam sua leitura mais abrangente. Tomada de empréstimo à filosofia e à psicologia, Stam (2013) argumenta que a noção de reflexividade no cinema foi estendida para a autorreflexão de um meio ou linguagem. O autor destaca a autoconsciência metodológica do termo e sua capacidade de investigar os próprios instrumentos. "Em sentido mais lato, a reflexividade fílmica se refere ao processo pelo qual os filmes trazem a primeiro plano sua própria produção [...], sua autoria [...], seus procedimentos textuais [...], suas influências 
intelectuais [...] ou sua recepção" (Stam 2013, 174). A reflexividade viria como uma resposta ao cinemaespetáculo ao trazer em si as marcas do trabalho produtivo e suas consequentes fontes de produção e interesse que, se não torna patente, ao menos lança sob suspeita os traços que denunciam o cinema como "objeto trabalhado e como discurso" (Xavier 2014, 158). A opacidade, referida por Ismail Xavier em seu tratado sobre o discurso cinematográfico, ao encobrir a "janela do cinema", assinala a materialidade do fazer fílmico (na ação de construir).

Aproximando essa discussão do filme documentário, Nichols $(1988,49)$ comenta que a reflexividade torna explícito aquilo que sempre esteve em estado implícito no filme por meio do papel ativo do cineasta, tido como um participante-testemunha neste processo de fabricar significados e produzir um discurso cinematográfico. Da-Rin acrescenta ao comentário de Nichols a capacidade do realizador de problematizar as limitações do próprio meio de comunicação.

Não satisfeito em simplesmente expor um argumento sobre seu objeto, o cineasta passa a engajar-se em um metacomentário sobre os mecanismos que dão forma a este argumento. No lugar de uma ênfase absoluta sobre os personagens e fatos do mundo histórico, o próprio filme afirma-se como fato no domínio da linguagem (Da-Rin 2004, 170).

Neste jogo de "dar a ver", os documentários podem ser reflexivos de uma perspectiva tanto formal quanto política. Isso é o que propõe Nichols $(2016,205)$. Para o autor, enquanto a perspectiva formal nos convoca a refletir sobre a própria forma do documentário, de modo a nos levar a repensar a "suposição do valor de verdade" e até a própria credibilidade do que é dito, a perspectiva política conduz a uma reflexão para as expectativas "mais sobre o mundo histórico do que para a forma cinematográfica". Em uma perspectiva formal, tudo que é posto em cena é passível de questionamentos, assim como aquilo que, de alguma forma, foi ocultado. $\mathrm{Na}$ perspectiva política, o que conta é a consciência das imagens do mundo, que trazem em si convenções sociais, discriminações e dominações. As imagens, como quadros do mundo, carregam consigo as molduras políticas de seu enquadramento. Para algo ficar dentro, outros tiveram que ficar fora. Consequentemente, nos faz "enquadrar o enquadramento", nos termos da Trinh Minh-ha, ou seja, questionar que há algo de fora que torna "o próprio sentido de dentro possível, reconhecível" (Butler 2015, 24). Pelas imagens, podemos "nomear o que fica invisível", a exemplo da opressão e da hierarquia. Em resumo:

Como estratégia formal, tornar o familiar em estranho lembra-nos de como o documentário funciona como gênero cinematográfico cujas afirmações a respeito do mundo talvez acolhamos de maneira descuidada demais. Como estratégia política, ele nos lembra de como a sociedade funciona de acordo com convenções e códigos que talvez muito facilmente nos passem despercebidos (Nichols 2016, 206).
Resgatamos alguns pontos da metalinguagem, metafilme/metacinema, mise en abyme e da reflexividade para entender o que, de certa forma, os atravessa e converge naquilo que trataremos como a metanarrativa do documentário. Distante de refutar o que foi postulado anteriormente, buscaremos os pontos de interseção, interpretando a metanarrativa como algo que contém e também está contida nesses conceitos. A proposta é flexionar as ideias de modo a, como o próprio sufixo meta- sugere, colocar as imagens e sua elaboração sob suspeita. Posto isso, tomaremos de empréstimo da metalinguagem a capacidade de apontar para si, se autorreferir; do metafilme, a autofagia, considerando sobretudo os arquivos como referência, no qual um filme se constitui a partir dos restos de outros filmes; da mise en abyme nos interessa a característica abismal, a força centrípeta da imagem; e, por fim, da reflexividade a capacidade de elaboração em ato.

A metanarrativa constrói a dialética do olhar que direciona tanto para o universo diegético quanto para fora dele, "construindo e desnudando, simultaneamente" (Carreira 2005). Consideraremos, assim, a narrativa não no processo de elaboração da escrita, mas em sua reelaboração, no metatexto (na escrita sobre a escrita das imagens de arquivo). $\mathrm{Na}$ insatisfação de ter um arcabouço teórico que preencha de sentido a metanarrativa, recorreremos à própria imagem como objeto descortinador deste conceito. É pela imagem, ou melhor, é com as imagens que buscaremos construir uma compreensão, decerto não totalizante, mas que aponte um caminho para esta dimensão metanarrativa no documentário, sobretudo no documentário com imagens de arquivo, que traz consigo suas especificidades.

\section{A natureza das imagens sob suspeita}

Para João Moreira Salles, um documentário encerra duas naturezas distintas: é ao mesmo tempo registro de algo que aconteceu no mundo e narrativa, ou seja, uma retórica construída sobre o que foi registrado (Salles 2005, 64). Essa retórica, em seus filmes-ensaio, parte tanto do exame das imagens (que desencadeia o discurso na forma da voz over e que, por vezes, convoca o antecampo) quanto da sua confrontação com outros documentos (imagéticos ou sonoros) em uma montagem que, ao entrecruzar os acontecimentos, não deixa de ser, por si, também uma forma de discurso, ao narrar os fatos pelo encadeamento de recortes heterogêneos e anacrônicos.

Segundo Salles $(2004,07)$, todo documentário é "uma representação do mundo e toda representação precisa justificar seus fundamentos". Ao comparar o documentário Nanook do Norte (1922), de Flaherty, com Ao redor do mundo, dirigido pelo major Luiz Thomaz Reis nas expedições da Comissão Rondon, Salles chama atenção para esse ato de representação. Em Flaherty, o diretor vê a "gramática do cinema" e a escrita do filme, ou seja, está ali todo o arsenal da cinematografia clássica aperfeiçoada por 
Griffith a serviço da história (Salles 2005, 63-4). Na obra do major Reis, com cenas rodadas entre 1912 e 1917, portanto, anteriores a Nanook, Salles vê "um importante registro", um procedimento de antropologia partilhada, mas apenas isto: "um registro". "As imagens se justapõem sem nenhuma necessidade interna", descreve. A diferença, distingue Salles, é que para um documentarista "a realidade que interessa é aquela construída pela imaginação autoral" (ibid., 63). Uma construção que se manifesta tanto na filmagem como na montagem.

Em referência a afamada frase-síntese de John Grierson - que define o documentário como o "tratamento criativo da realidade" ${ }^{3}$-, Salles (Ibid., 64-5) detém-se ao substantivo "tratamento" para assinalar o indício de transformação que o documentário evoca e ao adjetivo "criativo" como aquilo que deflagra $o$ ato de pôr os processos em elaboração. O tratamento criativo incita o manuseio do documentarista, o fazer documentário, uma forma de se relacionar com os objetos do mundo. Na metáfora de Grierson, o documentário não é um espelho voltado para a natureza, mas um martelo que forja essa natureza (Grierson apud Da-Rin 2004, 93). Afinal, "documentários não são exatamente sobre os outros, mas sobre como documentaristas mostram os outros. A representação de qualquer coisa, é a criação de outra coisa" (Salles 2005, 67). Salles, com isso, destaca a materialização do olhar do documentarista sobre o mundo traduzidas em imagens que, mais do que carregar traços do outro, estão imbuídas das marcas de quem as forjou. E, justamente por isso, devem estar sempre sob suspeitas.

De certo modo, a proposta de investigar a natureza das imagens, citada e largamente repetida por João Moreira Salles em suas últimas entrevistas, advém dessa inquietação. Este impulso de não tomar a imagem por seu valor de face ganha corpo em Santiago e, posteriormente, novas dimensões em No Intenso Agora. Em Santiago, JMS inicia o processo de escrita durante a edição, ou seja, o filme nasce em função da imagem:

(1) Montagem (edição em função da imagem) $\rightarrow$ (2) Escrita do texto (escrevia/reescrevia o texto a partir das imagens editadas) $\rightarrow$ (3) edição (reeditava-se as imagens em função do texto).

JMS passou a dizer, após concluir Santiago, que para ele só seria possível fazer filmes que contemplassem este duplo movimento do olhar: para dentro (do próprio filme) e para fora. Filmes que de alguma forma se pensem. Santiago foi montado em cima dos restos do filme de 1992. Um método que atravessa o material, convoca a matéria esquecida, recalcada, apagada na condição de rastro. É essa experiência que o diretor leva para No intenso agora. As imagens partem da esfera íntima, com os arquivos da mãe na viagem à China, e expandem o olhar para fora, para o social.

\section{Formas da metanarrativa: voz over, montagem e antecampo}

A premissa de analisar a metanarrativa como processo que evidencia o ato de extrair a natureza das imagens se justifica por ser um gesto consonante ao que João Moreira Salles intenta construir em seus filmes-ensaio. Em busca de acentuar algumas questões da metanarrativa no documentário, dividiremos a análise com base em três operadores: a voz over, a montagem e o antecampo, que nos servem, por hora, como esforço para ir ao encontro das imagens. São operadores indissociáveis (sendo isso uma de suas potências) e que, portanto, servem mais ao papel, no exercício de análise, do que propriamente à intertextualidade das imagens no filme, mas que não deixam de ser um instrumento que nos permite ater a alguns detalhes de cada categoria no intuito de revelar a identidade multifacetada da metanarrativa.

$\mathrm{Na}$ ação de retomar as imagens em Santiago e No intenso agora, a voz over é uma das principais ferramentas que materializa o processo de trazer o passado ao presente. Um ato metanarrativo, uma vez que busca compreender o que esses arquivos evocam da memória íntima, mas também o que eles evocam enquanto imagem.

Em Santiago a suspeição das imagens é explicitamente posta em cena. JMS filmou algumas imagens em estúdio que serviriam, a princípio, para ilustrar o depoimento de Santiago: um trem de ferro de brinquedo, um vaso de flores, um boxeador. A estratégia de utilizar "imagens de cobertura" é comentada pelo diretor logo no início do filme, quando expõe partes do que seria o roteiro do filme em 1992, para em seguida apresentar a única sequência montada que sobrou daquela época. O projeto original ficou inacabado. As ideias sucumbiram à edição. Em agosto de 2005, JMS decide reabrir os arquivos do filme. Nove horas de material filmado, 30 mil páginas datilografadas por Santiago e as memórias do diretor subsidiaram a nova montagem, uma "reflexão sobre o material bruto", como ele resume na cartela que acompanha o título do filme.

Na qualidade de mediadora, a voz over propõe uma visita guiada por esse material. Uma espécie de alter ego do diretor, uma vez que na narração em off é seu irmão, Fernando, quem empresta a voz (propriamente a voz do diretor também está inscrita no filme, mas advém do antecampo, que trataremos adiante). É pela voz over que JMS convida o espectador a pôr o documentário em crise. Ao resgatar as cenas do boxeador feitas em estúdio, o filme questiona o grau de interferências que elas podem ter sido submetidas. "Interferíamos a ponto de maquiar o boxeador? De exagerar seu suor?", pergunta, enquanto a imagem mostra o perfil do lutador, cujo suor escorre como se brotasse de uma mina. "Assistindo ao material bruto, fica claro que tudo deve ser visto com uma certa desconfiança", emenda. Essa desconfiança é a base para a construção do filme, seu leitmotiv. $O$ convite à dúvida flexiona o processo fílmico sobre o próprio filme e estende o procedimento ao espectador, 
que, atendendo ao chamado, não só acompanha a suspeição das imagens como passa também a interrogar o que é posto em cena.

Santiago traz a todo momento cenas em que a voz over alude ao fazer fílmico, cenas que interpelam as próprias escolhas. Em uma delas, o mordomo Santiago comenta sobre a Casa da Gávea, casarão que abrigou a família Salles no Rio de Janeiro e onde durante 20 anos foi responsável, entre outras coisas, pelos arranjos florais que ornamentavam os salões e as festas. Ele está de pé e fala olhando para a parede. Um enquadramento um tanto inusitado para um documentário calcado em entrevistas e distante do modelo observacional. Como a mise en scène foge do vivido e causa uma ruptura entre o corpo e o espaço que ele ocupa, o enquadramento salta aos olhos. Tenta naturalizar algo que tem um fundo performático. Ao rever o material, JMS esforça-se para resgatar da memória o que o teria levado a tal enquadramento. "Hoje, já não sei por que, mas pedi a Santiago que me falasse de flores, de pé e olhando para a parede". A falta de uma resposta é sintomática. Uma lacuna que nem sempre é possível preencher e, que em sua incompletude, desvela o cerne das questões mnemônicas: para lembrar é preciso antes esquecer e, uma vez no limbo do esquecimento, nem tudo é passível de ser resgatado. Algo sempre se perde.

A voz over também opera como principal ferramenta metanarrativa em No intenso agora. Em uma das primeiras sequências do filme, observamos uma mulher atravessar a rua de mãos dadas com as duas filhas ainda pequenas. Na extremidade da cena, a babá, com um lenço na cabeça, carrega a filha menor da patroa em um dos braços e com a outra mão se une ao cordão das crianças e da mãe para atravessar a rua.

A cena seguinte mostra elas já no passeio. A criança que antes estava no colo agora está de pé na calçada. A pequena começa a andar, diante daquilo que pode ser o registro de seus primeiros passos pela câmera. Nesse momento, a babá sai do quadro. "A câmera pensa que está registrando apenas os primeiros passos de uma criança. Sem querer mostra também as relações de classe no país".

A ação dos primeiros passos volta a ser exibida e, desta vez, o diretor chama a atenção para a questão social inscrita na imagem que, em uma primeira apreciação, pode passar desatenta ao espectador. "Quando a menina avança, a babá recua. Ela não faz parte do quadro familiar e muito provavelmente sem que ninguém peça vai ocupar o fundo da cena, onde se confunde com os passantes", diz. "Nem sempre a gente sabe o que está filmando", emenda em uma citação não literal e não credita a Chris Marker, emprestada do documentário O fundo do ar é vermelho (1977), que também versa sobre o maio francês.

Como arqueólogo das imagens - ou trapeiro, em uma figura benjaminiana -, JMS busca escavar os restos dos arquivos, as sobras das imagens e transporta essa escavação para o fazer fílmico. Retomando o pensamento de Nichols (1988), ele explicita aquilo que sempre esteve em estado implícito.
No exame detalhado da imagem, este narradortrapeiro buscar extrair vestígios de um passado ainda presente, incrustado por outras camadas (temporais, político-sociais, hierárquicas, simbólicas). Se "nunca se sabe o que se filma", como diz Marker, cada rastro que escapa, por menor que seja, acende a incerteza do registro. O detalhe da babá, certamente, nos passaria desapercebido, tomados pela ação da criança em primeiro plano. É a voz over quem nos alvitra essa observação, não sem antes nos testar. Em No intenso agora, JMS elabora um jogo metanarrativo. Primeiro, ele exibe a imagem e, na sequência, a retoma para desnudá-la, num jogo de autoconsciência narrativa.

Indagar com minúcia as imagens requer um esforço sobre elas. Mantendo a metáfora do Grierson, são detalhes forjados e não dados. É na retomada dos arquivos (possivelmente feita em exaustão na montagem) que esses detalhes incrustados ganham formas perceptíveis.

Esse jogo metanarrativo também deflagra o segundo operador analítico da pesquisa: a montagem, que incorpora a organização discursiva e o tratamento das cenas como um dispositivo que descortina seu processo criativo. Se as imagens de arquivo são "obscuras como hieróglifos", como afirma DidiHuberman, é na ação de escavá-las que elas se abrem "brutalmente a um mundo desconhecido", uma fissura no espaço-tempo que nos fornece "o "esboço vivo' da interpretação a reconstruir" (Didi-Huberman 2012, 130). Reconstruir, neste caso, indica tanto o caráter heterogêneo e lacunar da escrita com os arquivos como seus anacronismos e, dessa maneira, a porosidade das memórias. É também reconstrução porque convoca a montagem, o cruzamento com outros recortes, outras temporalidades.

Ao dissecar uma das imagens que compõe No intenso agora, João Moreira Salles busca na ação pormenor algo que possa, em sua visão, caracterizar o confronto nas ruas. O diretor narra que do "acervo de gestos de 68" este é o mais marcante: "o corpo vergado para trás, o braço em estilingue, a energia represada a um segundo da descarga. O giro de atleta olímpico. E, quase sempre, o recuo". A narração é endossada por uma imagem em câmera lenta (Figura 1), um recurso feito na montagem que evidencia o movimento, como quem quer acentuar a tônica da imagem. O procedimento lembra os estudos do inglês Eadweard J. Muybridge (1830-1904), inventor do zoopraxiscópio, e sua série de fotografias na década de 1880, com o objetivo de mapear e analisar a anatomia do movimento humano. 


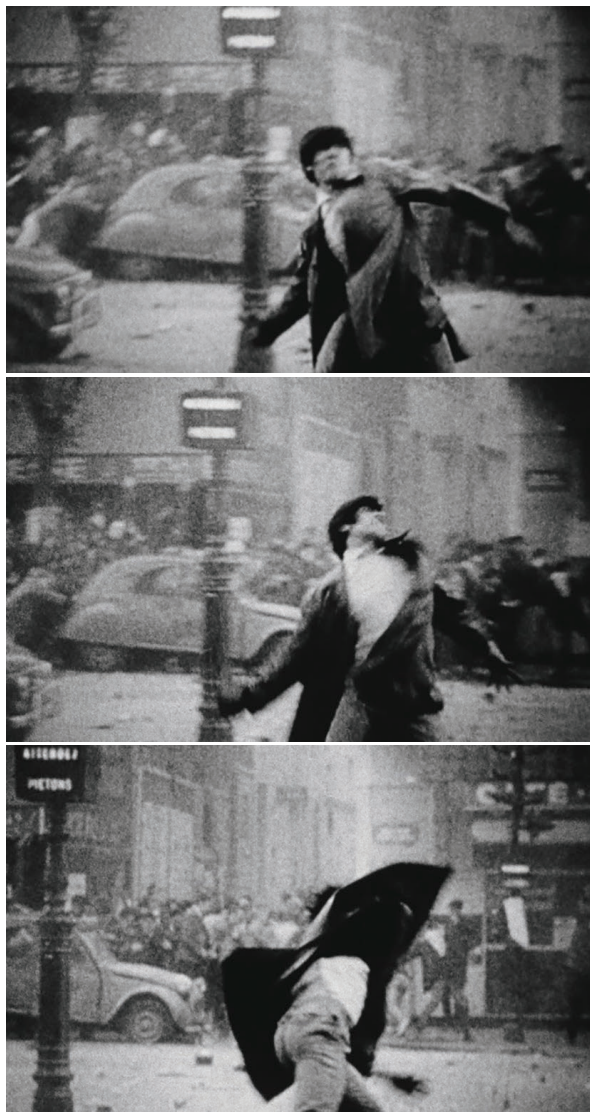

Figura 1 - Câmera lenta: arremesso de uma pedra por um dos manifestantes em maio de 1968, em Paris. Fonte: No intenso agora (João Moreira Salles, 2017 / @iskra)

Se "cada segundo ganhou a espessura da eternidade" no maio de 1968, como escreveu um dos estudantes da Sorbonne, não poderia ter melhor recurso de linguagem cinematográfica para representar esse sentimento em imagens do que a câmera lenta, a análise quadro a quadro, o congelamento (ou a dilatação) do tempo para dar destaque ao movimento da ação. Em uma das cenas dos conflitos com a polícia, uma jovem corre na direção oposta, onde parece ter uma das barricadas bem ao fundo. João Moreira Salles opta, em um outro momento, por reexibir essa cena em câmera lenta até fixar em um frame. A velocidade de exposição dilatada permite ver melhor a expressão no rosto da jovem. Ela está feliz.

JMS parte de um tratado sobre a felicidade e seu caráter efêmero para analisar alguns dos movimentos sociais que marcaram 1968. Em seu filme-ensaio, a felicidade é transeunte. Ela não é condição do ser, mas um estado das coisas, portanto é algo com prazo de validade, às vezes até demasiadamente fugaz. Se postas em camadas sucessivas, a questão filosófica talvez seja a uterina, aparentemente de menor escala, porém a base fulcral do diretor para a construção de todas as outras. Na esfera oposta, o debate político possivelmente seja a camada exterior, a leitura mais abrangente e a que melhor se encaixa aos diferentes contextos de apreensão da obra. O fluxo segue, então, do particular (as imagens de arquivo da sua mãe e a experiência feliz daquela passagem pela China maoísta) para o geral (a utopia das manifestações populares e a alegria catártica do momento).

A partir dessa hipótese, JMS constrói ao longo de todo o filme um mosaico sobre a felicidade, valendo-se dos freeze-frames (quadros congelados) para tecer seu comentário visual (Figura 2). Por vezes, as imagens são apresentadas no filme com a velocidade de exposição natural e retomadas posteriormente como imagem congelada. Ao recuperá-las, a irrupção do fluxo contínuo da ação para o congelamento do quadro coloca em relevo a montagem, expondo não só o dispositivo, mas o discurso da subtrama: a felicidade do agora na intensidade do vivido.

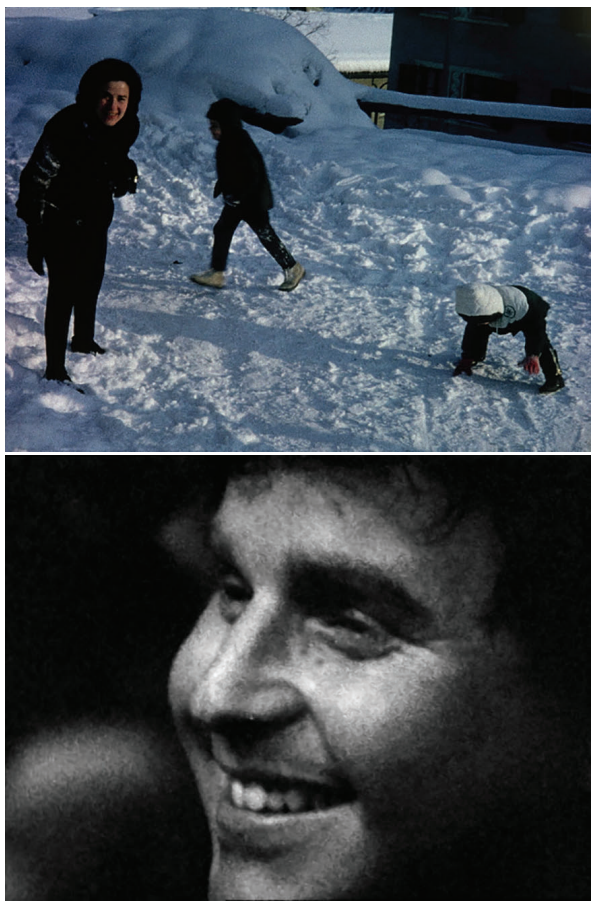



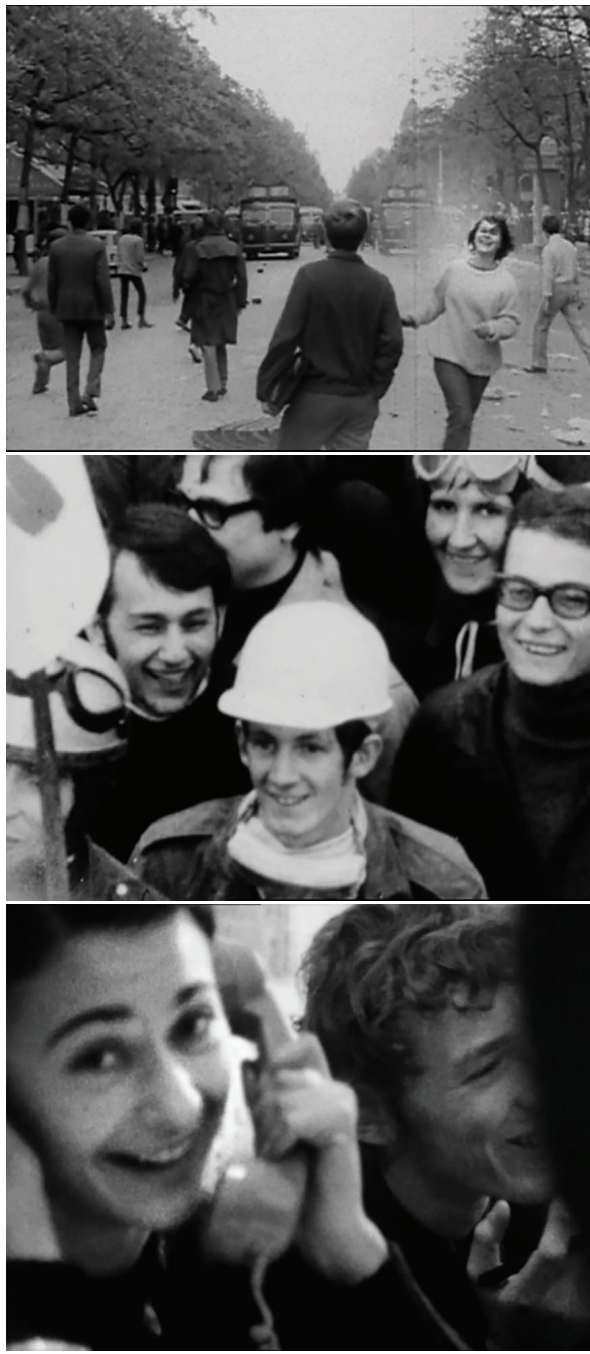

Figura 2 - Compilação de cenas congeladas (freeze-frames). Reúne imagens captadas ao longo de todo o filme, que destacam o sorriso no semblante dos sujeitos. Fonte: No intenso agora (João Moreira Salles, 2017)

Em Santiago, essas construções narrativas são mais ordenadas, o que facilita a apreensão do filme como um processo e um produto, mas nem por isso deixa de ter múltiplas camadas. Após a voz over apresentar a piscina da Casa da Gávea, ela detalha que três planos foram feitos naquele local. No terceiro, uma folha cai no fundo do quadro. "Visto agora, treze anos depois, a folha me pareceu uma boa coincidência. Mas quais são as chances de, logo no take seguinte, outra folha cair no meio da piscina", questiona, para depois duvidar se a ondulação na água não teria sido agitada por "uma mão fora de quadro". A reflexividade dessa sequência é nítida não só pela linguagem que remete diretamente ao universo cinematográfico: plano, take, fora de quadro -, em uma narração que se centra em seus próprios mecanismos de construção, mas ao incorporar na montagem os restos, as sobras, as bordas do filme de 92, como bem examinou Feldman "aquilo que ele não mais é", o que "deixou de ser" (Feldman 2007, 01).

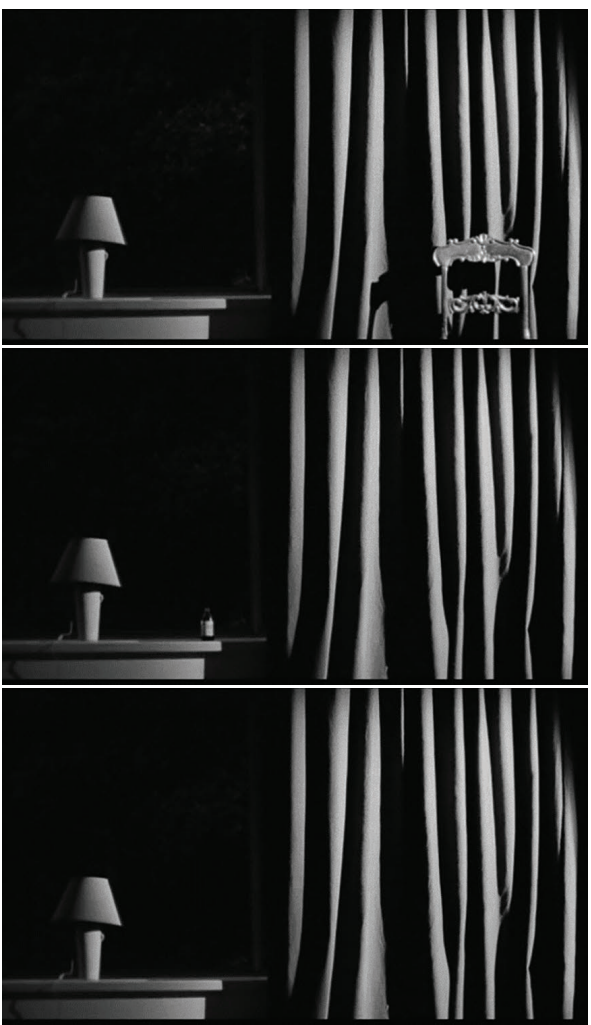

Figura 3 - Sequência em que a composição dos objetos em cena é questionada pela voz over sobre a "realidade" do espaço ou sua interferência em busca do "quadro perfeito". Fonte: fotogramas do filme Santiago (João Moreira Salles, 2006)

Estas imagens (Figura 3) antecipam o olhar de desconfiança sobre o material bruto que o diretor propõe. Certamente, não figurariam as três juntas no projeto original. Delas, uma seria eleita, as outras descartadas. Mas qual? O abajur e a cadeira? O abajur com a garrafinha? Só o abajur? O objeto, neste caso, pouco importa. Interessa a mise en scène que deflagra o próprio "pôr em cena", a imagem que nasce do "tratamento criativo" e, nem por isso, é menos documental. A sequência põe em evidência o fazer fílmico, documenta os procedimentos do filme e, com isso, nos faz questionar o grau de intervenções que uma imagem pode ser submetida.

Por fim, como última categoria de análise 
propusemos avaliar o antecampo como instrumento metanarrativo. Tomaremos esse recurso como uma espécie de fora-de-campo mais radical, que "nem sempre pertence ao mesmo espaço ficcional do campo" (Aumont 2004, 41). Segundo Brasil, o antecampo seria esta forma particular de extracampo, atrás da câmera, que abriga o diretor e sua equipe, "um espaço ético que não deixa de ser recurso estilístico e recurso estilístico que não deixa de ser espaço ético" $(2013,578)$.

No documentário, precisamente, a aparição do antecampo é historicamente movida por ao menos duas demandas: de um lado, a abertura ao dialogismo (no compartilhamento dos sujeitos na mesma mise en scène e na tentativa de aproximação); de outro, a reflexividade crítica (os impasses, as cisões, os entraves dessa aproximação), explica Brasil (2013, 582). O autor ainda lembra que, ao adentrarem na cena, os sujeitos que habitam o antecampo, de certo modo, ficcionalizam-se e passam a compor o espaço da representação. Por outro lado, em decorrência de tal gesto, a representação é fendida e passa a "abrigar, processualmente, uma relação de mútua implicação e alteração entre quem filma e quem é filmado, entre mundo vivido (extradiegético) e mundo fílmico (diegético)" (Brasil 2013, 579).

O antecampo é a todo momento, e sob diferentes formas, convocado em Santiago. Já no começo do filme João Moreira Salles expõe um pequeno fragmento em que aparece ao lado de seu personagem. Na imagem congelada, não vemos o rosto de JMS, que aparece de costas para a câmera, tampouco o de Santiago, que fica posicionado atrás do diretor, mas os dois dividem a mesma mise en scène. De todo o material, a voz over pontua que esta é uma das duas únicas imagens em que os dois aparecem juntos (Figura 4).

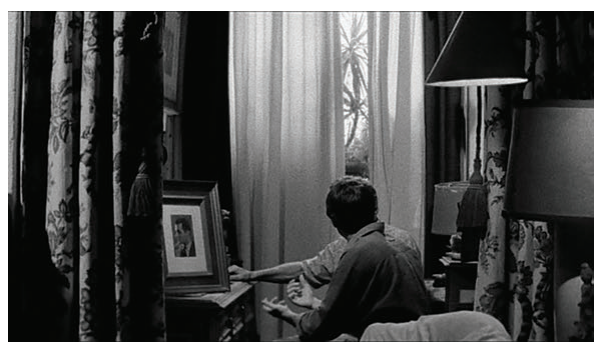

Figura 4 - João Moreira Salles (de costas) conversa com seu personagem, Santiago (ao fundo). A imagem é apresentada no filme com um ligeiro gesticular dos braços do diretor que se fixa em um frame por alguns segundos. Sobre a imagem congelada, JMS comenta o início de um novo relacionamento entre eles, agora como diretor e personagem. Fonte:

fotogramas do filme Santiago (João Moreira Salles, 2006).

A cena poderia sugerir uma simbiose entre os dois personagens, sentados, ao mesmo nível, um de frente para o outro, tecendo memórias que se cruzam. De fato, Santiago traz as lembranças do personagem-título, as experiências vividas por ele, o gosto pela erudição, mas o filme documenta antes a história da família Salles, sobretudo aquela vivida no casarão imponente que personifica o banqueiro, embaixador e patriarca da família: Walther Moreira Salles. Seria inocente pensar essa simbiose como uma associação mutuamente nivelada para os dois personagens. A relação de classes se inscreve nas imagens e o antecampo expõe essa hierarquia. Não é à toa que a primeira palavra do diretor que surge do antecampo é um "inequívoco não", como destaca Feldman $(2007,01)$. A negativa atesta a figura do diretor, quem controla os caminhos do filme. A recusa em aceitar o depoimento de Santiago, da forma como ele sugeria estará, de alguma maneira, em todo o filme, ainda que implícita.

O "não" revela a relação diretor/personagem tal como outros imperativos que emergem ao longo do filme: "vai", "deixa rolar", "a gente está filmando, vai", "fala Santiago [...] fala para mim", "fala isso pra gente". A palavra de ordem, na hierarquia do cinema, vem do diretor e o filme faz emergir essa tessitura das relações. Não é de surpreender que, ao examinar o material bruto, JMS deflagre a relação servilista de Santiago. "Desde o início, havia uma ambiguidade insuperável entre nós que explica o desconforto de Santiago", diz a narração. E continua: "é que ele não era apenas meu personagem, eu não era apenas um documentarista. Durante os cinco dias de filmagem, eu nunca deixei de ser o filho do dono da casa; e ele nunca deixou de ser o nosso mordomo".

No mea-culpa de JMS está a metanarrativa tanto em sua perspectiva formal quanto política, retomando a análise sugerida por Nichols. Ao mesmo tempo que ele coloca em crise aquilo que é posto em cena, ciente da construção das imagens do cinema, ele "enquandra" o seu próprio enquadramento, expõe os códigos sociais, numa consciência das imagens do mundo. Um gesto franco, mas ainda assim estratégico, como observou Ilana Feldman. "Afinal, toda impiedosa autocrítica é uma forma de blindagem contra a crítica alheia" (Feldman 2007, 01)

Durante todo o filme, Santiago se expressa através da câmera (para detrás da câmera), consciente de sua própria construção performática. Ele gesticula com os braços, convocando o antecampo a completar seu raciocínio, a lançar novas questões para os seus comentários. Segundo Brasil (2013), em alguns casos, "o antecampo é sugerido menos pela aparição do diretor do que pela maneira como o sujeito filmado devolve o olhar à câmera ou se dirige à equipe tornando presente, quase tangível, aquilo que não é concretamente visível".

Uma das cenas que exemplificaria esse antecampo metanarrativo não se dá nem com imagens. Em uma tentativa de estabelecer um diálogo entre personagem e diretor, Santiago propôs recitar um pequeno soneto no qual assinala o seu pertencimento a um grupo específico: o "núcleo de seres malditos". A voz de Santiago é ouvida sobre uma tela preta. JMS não ligou a câmera. Possivelmente esse registro não estaria no primeiro roteiro. É resto, sobras do arquivo. Foi no processo de prensar as imagens, mais de uma década depois, que ele atentou que aquele momento interrompido talvez fosse o mais íntimo de Santiago. Nele, o ex-mordomo consegue romper a amordaça e chama o diretor pelo nome: para ele, "Joãozinho". 


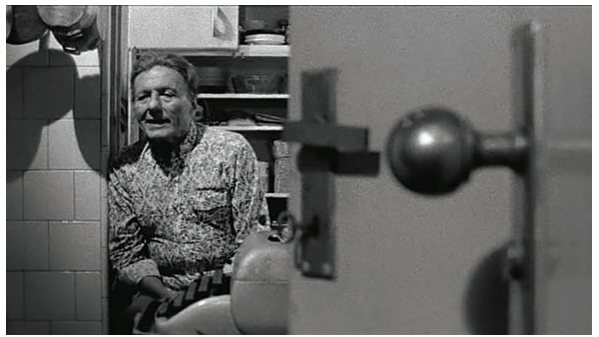

Figura 5 - Os enquadramentos em Santiago restringem o espaço do personagem, pondo-o em segundo plano na imagem. Fonte: fotogramas do filme Santiago (João Moreira Salles, 2006).

Em Santiago, o personagem-título foi confinado não só à mise en scène que circunscrevia o seu espaço de ação e, por vezes, conferia-lhe um segundo plano (como nas cenas em que Santiago está sentado ao fundo da cozinha e a maçaneta da porta figura em primeiro plano - Figura 5), mas também nas regras impostas pelo diretor na época das filmagens, que ditou limites ao testemunho do personagem (Santiago, por exemplo, não podia citar os nomes dos membros da família Salles). "Joãozinho" é aquilo que atravessa a materialidade das imagens e explicita a relação assimétrica dos sujeitos estabelecidas entre o mundo fílmico (personagem e diretor) e o mundo vivido (sensível a memórias remotas do mordomo e seu outrora aprendiz mirim).

Diferentemente de Santiago, em No intenso agora JMS não opera no antecampo, já que o filme é (com exceção de uma cena) todo feito com imagens de arquivos (de outros documentários, de coletivos de cinema, acervos institucionais, cinejornais, etc). É na função de escavar as imagens, que ele convoca o antecampo. Ao invés de atuar nesta forma particular do extracampo, JMS vai, pela voz over, questionar esse espaço.

Dos arquivos do fim da Primavera de Praga, na Tchecoslováquia em 1968, o diretor seleciona dois extratos: "Rolo 25" e "Rolo 127", assim referidos no filme, produzidos por realizadores anônimos. Enquanto "Rolo 25" documenta os fatos, "Rolo 127" tenta construir uma história da ocupação. Começa com as imagens dos líderes soviéticos, depois um registro da data e o local (feita em um mapa) e o desdobramento dos acontecimentos pelas imagens de TV. Diferente de "Rolo 25", "Rolo 127" desce para a rua e tenta se aproximar da ação. São imagens tremidas e com muito zoom até o desfecho, que mostra a chegada da delegação soviética ao aeroporto. Esse epílogo volta a ser feito pela televisão de uma maneira que João Moreira Salles descreve como um "ato de resistência". O fim da política é captado pelo simulacro das imagens no ecrã. JMS lembra que filmes amadores como esse existiram porque a democracia não acabou da noite para o dia. "Acho que a maioria desses amadores filmou por impulso. Porque era a história acontecendo e eles eram a parte fraca. Só o que podiam fazer era prestar testemunho", diz em voz over.
"Rolo 25" e "Rolo 127" trazem a urgência do registro, a incerteza do futuro e a insegurança do passado como vestígio. Como o "passado passa" e a memória não se fixa, as imagens assumem o papel da rememoração. Em NIA, a voz over vasculha os restos e com os rastros tenta reelaborar o passado, por vezes ao interrogar o antecampo. Afinal, as imagens dos rolos não são impessoais, "refletem a perspectiva de alguém, uma testemunha que filma o relógio de pulso para registrar a hora dos acontecimentos", reforça a voz over. Em um dos trechos do "Rolo 127", vemos um dos tanques da força invasora, liderada pela União Soviética, ocupando a cidade. Com cuidado para se expor, "Rolo 127" documenta da sacada de um edifício. A câmera treme ao passar para dentro do cômodo. Neste momento, alguém atravessa diante da lente. Essa é a chave que aciona o questionamento do diretor sobre o antecampo: "na mesma hora vem à cabeça a existência de uma família ou ao menos de um círculo social que agora está sob ameaça e precisa da proteção da cortina".

O antecampo lembra que, por trás da câmera, há um mundo vivido e que seu contexto político-social incide diretamente sobre a imagem produzida. Esse pensamento é interseccionado no filme a fim de estabelecer o cotejo entre o arquivo imagético de 68 na França e na Tchecoslováquia. Com isso, NIA questiona o que as imagens podem dizer sobre o regime político na qual ela foi realizada só pelo enquadramento ou pela forma de registro. Um questionamento que evoca a pergunta de Marker, em O fundo do ar é vermelho: por que é que, às vezes, as imagens começam a tremer?

No maio francês elas foram feitas em um cenário de insurgência, mas ainda assim em uma democracia. $\mathrm{Na}$ Tchecoslováquia, onde a liberdade não era total, as imagens são emolduradas por frestas, cortinas e teleobjetivas. "A imagem treme. O fotógrafo se esquiva de um eventual tiro ou da mirada de um soldado. Essas coisas fazem parte do registro. Dão vida ao documento" 4 , resume JMS.

A convocação do antecampo abala o regime representativo clássico. Uma construção diferente de Santiago, onde o antecampo se manifesta no ato da filmagem. Em NIA, ele expressa-se na montagem, na reelaboração dos arquivos. Um olhar que, ainda que não participante, é situante e expõe os sujeitos que sofrem, em retorno, "os afetos do mundo" (Brasil $2013,580)$.

\section{Conclusão}

Apesar de os filmes documentários serem construídos e consumidos segundo convenções narrativas, essas particularidades ainda são pouco debatidas (cf. Coelho 2011, 26). As dificuldades esbarram desde a estruturação de um aporte teórico, visto que a literatura sobre o tema ainda é escassa (principalmente comparada a ficção) e a transposição de outros estudos sobre a narrativa (como na Teoria Literária) é incipiente e não abarca a complexidade do objeto de estudo.

Nesse sentido, o esforço para dissecar a dimensão 
extensiva da metanarrativa, proposta neste artigo, contribui, ainda que de maneira singela, para alavancar outras formas de apreender o filme documentário. Pela análise das imagens em Santiago e No intenso agora, inferimos a metanarrativa não apenas como a ideia de adentrar ou revelar os mecanismos de produção do filme, do dispositivo cinematográfico, mas de se constituir sobre esse processo. Uma inflexão sobre si, autoconsciente de sua narrativa, que não só expõe, mas acentua o método. Uma narrativa centrípeta que aponta para a imagem e nos conduz a "enquadrar o enquadramento", em um exercício de "construir e desnudar".

Santiago foi um ponto de virada na filmografia de JMS e deu início aos questionamentos do fazer fílmico como procedimento imanente do documentário. Uma narrativa costurada na montagem (na ilha de edição) que dobra sobre si e passa a investigar os aparatos que Ihe dão forma, naquilo que Stam (2013) chama de "autoconsciência metodológica", ou seja, sua tendência a examinar os próprios instrumentos. É esse movimento que JMS transporta para No intenso agora ao combinar uma série de acontecimentos diferentes da década de 1960, a partir da experiência de sua mãe na China de Mao Tsé-Tung.

Pela voz over e pela montagem, a metanarrativa nos filmes analisados opera como um mecanismo que conjuga duas linhas: os discursos que ressoam no filme (e reverberam internamente), expondo o processo que ali se elabora, e as imagens (e suas confluências). Entendendo essas duas linhas não como paralelas que cortam o horizonte fílmico, mas como fios contíguos, cujos pontos de interseção dão a ver, ora mais, ora menos, o próprio pensar fílmico.

Mesmo tomando os arquivos como ponto comum, a metanarrativa que opera pelo antecampo, por sua vez, assinala a diferença da natureza das imagens nos dois documentários. Em Santiago, o diretor atua no antecampo, a ponto de poder compartilhar a mesma mise en scène, em NIA só lhe cabe convocar os sujeitos pelas imagens. No ato de escavar essas imagens, ele busca compreender o testemunho imagético de quem filma, o que o enquadramento diz do espaço desse sujeito e o que o campo é capaz de revelar sobre a realidade implícita do antecampo.

Pelo cotejo entre os filmes-ensaio de JMS, é possível concluir que o jogo metanarrativo que se constitui vai além da mera exibição dos aparatos que tornam a ilusão do cinema possível para pôr em crise as questões éticas (dos dilemas, dos artifícios, da opressão, das hierarquias) que sustentam a narrativa, deflagradas na suspeição das imagens como método fílmico.

JMS inscreve em Santiago e NIA a inquietação do passado na sua lida com o presente e busca, ao revisitar as imagens de arquivo - de preferência os registros amadores - abrir a história para a pluralidade. É por meio desse material que o diretor percorre à procura de rastros e restos desse passado que "não foi feito para a história", como os diários audiovisuais da mãe e o testemunho de seu ex-mordomo, ou "filmados com urgência" pela imposição da ação presente, como as imagens captadas no fim da Primavera de Praga ou na efervescência do maio de 68. Ao escavar os arquivos em NIA, João Moreira Salles desperta a memória íntima, familiar e a expande para as manifestações sociais, em diálogo com o mundo em ebulição. Diferentemente de Santiago, no qual os restos de um filme inacabado, que compõe uma história pessoal, se abrem para a história do cinema e da natureza do documentário onde a dimensão maior é uma política das imagens que se quer aberta ao outro.

\section{Notas finais}

1 O presente trabalho foi realizado com apoio da Coordenação de Aperfeiçoamento de Pessoal de Nível Superior - Brasil (CAPES) - Código de Financiamento 001.

${ }^{2} \mathrm{O}$ efeito Droste se refere à embalagem de cacau da marca holandesa Droste, de 1904, que estampa uma mulher que segura uma bandeja com a caixa de embalagem do mesmo produto, ou seja, uma imagem recursiva, em versão menor.

${ }^{3}$ Manuela Penafria explica que Grierson, em seus princípios sobre o documentário (First principles of documentary), não diz claramente que o documentário é "o tratamento criativo da realidade", mas a frase tornou-se uma espécie de síntese do seu pensamento. (Cf. Penafria 2004, 193-94).

4 Entrevista concedida ao jornalista Rodrigo Fonseca disponível em: https://www.omelete.com.br/filmes/no-intensoagora-queria-saber-o-que-uma-imagem-diz-sobre-o-regimepolitico-em-que-foi-feita-diz-diretor.Acedido em 10 de maio de 2019.

\section{Bibliografia}

Andrade, Ana Lúcia. 1999. O filme dentro do filme: a metalinguagem no cinema. Belo Horizonte: Ed. UFMG.

Aumont, Jacques e Michel Marie. 2003. Dicionário teórico e crítico de cinema. Campinas: Papirus.

Aumont, Jacques. 2004. Lumière, "o último pintor impressionista". In O olho interminável [cinema e pintura], 25-46. São Paulo: Cosac Naify.

Brasil, André. 2003. Formas do antecampo: performatividade no documentário brasileiro contemporâneo. In Revista Famecos - Mídia, cultura e tecnologia, vol. 20, n. 3, 578-602. Porto Alegre: PPGCOM/ PUCRS

Butler, Judith. 2015. Vida precária, vida passível de luto. In Quadros de guerra: quando a vida é passível de luto? $1^{\text {a }}$ ed., 13-55. Rio de Janeiro: Civilização Brasileira.

Chinita, Fátima. 2013a. Metanarrativa cinematográfica: a ficcionalização como discurso autoral. In Atas do II Encontro Anual da Associação de Investigadores de Imagem em Movimento, ed. Tiago Batista e Adriana Martins, 40-54. Lisboa: AIM.

Chinita, Fátima. 2013b. O espectador invisível: Reflexividade na óptica do espectador em INLAND EMPIRE de David Lynch. Covilhã: Livros Labcom.http:// www.labcom-ifp.ubi.pt/ficheiros/20140611-201311 fatimachinita_espectadorinvisivel.pdf. Acedido em 5 de abril de 2019 .

Coelho, Sandra S. 2011. Perspectivas da análise narrativa no cinema: por uma abordagem narrativa no filme documentário, n. 11, 25-55. In Doc Online - revista digital do cinema documentário. Campinas: LabCom IFP, UBI, Unicamp.

Da-Rin, Silvio. 2004. Espelho Partido: tradição e transformação do documentário. Rio de Janeiro: Azougue Editorial. 
Didi-Huberman, Georges. 2012. Quando as imagens tocam o real. In Pós - Revista eletrônica do Programa de Pós-graduação em Artes da Escola de Belas ArtesUFMG, vol. 2, n. 4, 204-219. Belo Horizonte: PPG-Artes/ UFMG.

Feldman, Ilana. 2007. Santiago sob suspeita in Revista Trópico, ed. ago-set. http://pphp.uol.com.br/tropico/html/ textos/2907,1.shl. Acedido em 11 de junho de 2018.

Limoges, Jean-Marc. 2005. Mise en abyme et réflexivité dans le cinéma contemporain: Pour une distinction de termes trop souvent confondus. In Les Actes du 10e colloque estudiantin de la SESDEF, Département d'Études françaises de I'Université de Toronto, 1-21. Toronto: SESDEF. http://french.chass.utoronto.ca/SESDEF/miroir/ limoges.pdf. Acedido em 19 de maio de 2019.

Nichols, Bill. 2016. Introdução ao Documentário. 6a ed. Campinas: Papirus.

Nichols, Bill. 1988. The voice of documentary. In New challenges for documentary. Organizado por Alan Rosenthal, 48-63. Califórnia: University of California Press.

Penafria, Manuela. 2004. O filme documentário em debate: John Grierson e o movimento documentarista britânico. In Actas do III SOPCOM, VI LUSOCOM, II Ibérico, vol. 1. Organizado por António Fidalgo e Joaquim Paulo Serra, 185-195. http://www.bocc.ubi.pt/pag/penafriamanuela-filme-documentario-debate.html\#foot1046. Acedido em 20 de abril de 2019.

Salles, João M. 2004. Prefácio para Espelho Partido: tradição e transformação do documentário, de Silvio DaRin, 07-12. Rio de Janeiro: Azougue Editorial.

Salles, João M. 2005. A dificuldade do documentário. In O imaginário e o poético nas ciências sociais.Organizado por José Souza Martins et al., 57-71. São Paulo: Edusc, 2005.

Stam, Robert. 2013. Introdução à teoria do cinema. Campinas: Papirus.

Vanoye, Francis e Anne Goliot-Lété. 1994. Ensaio sobre a análise fílmica, $4^{\mathrm{a}}$ ed. Campinas: Papirus.

Xavier, Ismail. 2014. O discurso cinematográfico: a opacidade e a transparência. $6^{\mathrm{a}}$ ed. São Paulo: Paz \& Terra.

\section{Filmografia}

No intenso agora. 2017. De João Moreira Salles. Rio de Janeiro: Videofilmes. DVD.

Santiago. 2006. De João Moreira Salles. Rio de Janeiro: Videofilmes. DVD. 